\title{
Construction and Validation of the Adolescent Perceived Risks and Benefits of Exposure to Music From Personal Music Players Questionnaire
}

\section{Construcción y Validación del Cuestionario de Percepción de Riesgos y Beneficios de la Exposición a Reproductores Personales de Música Para Adolescentes}

\author{
Mónica Abraham \\ Universidad Tecnológica Nacional \\ Marcos Cupani \\ Instituto de Investigaciones Psicológicas del Consejo Nacional de Investigaciones Científicas y \\ Técnicas y de la Universidad Nacional de Córdoba \\ Ester Cristina Biassoni \\ Universidad Tecnológica Nacional \\ Ana Estefanía Azpilicueta \\ Instituto de Investigaciones Psicológicas del Consejo Nacional de Investigaciones Científicas y \\ Técnicas y de la Universidad Nacional de Córdoba
}

\begin{abstract}
Evidence has been found of an association between participation in risk behaviors and the perception of their risks and benefits. The use of personal music players (PMPs) is one of the most common non-occupational noise activities, especially among the young. The aim of the study was to develop a questionnaire to assess the positive consequences (benefits) perceived by adolescents and the negative consequences (risks) of listening to music on these devices. The construction and validation process occurred in 3 phases: item pool development; establishment of content validity; and estimation of construct validity, criterion-related validity, and internal consistency, with an accidental sample of 694 adolescents from 2 schools of Cordoba, Argentina. The results of the exploratory and confirmatory factor analyses revealed a 2-dimensional factorial structure. Together, both factors correctly classified $64.6 \%$ and $74 \%$ of adolescents with high and low exposure to music through PMPs. This questionnaire can be used to detect adolescents with risky listening and to develop strategies to promote protective behavior.
\end{abstract}

Keywords: personal music players, risk perception, benefit perception, instrument, adolescents

Se ha encontrado evidencia de una asociación entre la participación en conductas de riesgo y la percepción de sus riesgos y beneficios. El uso de reproductores de música personales (RPM) es una de las actividades de ruido no ocupacional más comunes, especialmente entre los jóvenes. El objetivo del estudio fue desarrollar un cuestionario para evaluar las consecuencias positivas (beneficios) percibidas por los adolescentes y las consecuencias negativas (riesgos) de escuchar música en estos dispositivos. El proceso de construcción y validación ocurrió en 3 fases: desarrollo de batería de ítems; establecimiento de validez de contenido; estimación de validez de constructo, validez de criterio y consistencia interna, en una muestra accidental de 694 adolescentes de 2 colegios de Córdoba, Argentina. Los resultados de los análisis factorial exploratorio y confirmatorio revelaron una estructura factorial de 2 dimensiones. En conjunto, ambos factores clasificaron

Mónica Abraham and Ester Cristina Biassoni, Centro de Investigación y Transferencia en Acústica, Universidad Tecnológica Nacional, Facultad Regional Córdoba, Argentina; Marcos Cupani and Ana Estefanía Azpilicueta, Instituto de Investigaciones Psicológicas del Consejo Nacional de Investigaciones Científicas y Técnicas y de la Universidad Nacional de Córdoba, Argentina.

Correspondence concerning this article should be addressed to Mónica Abraham, Centro de Investigación y Transferencia en Acústica, Universidad Tecnológica Nacional, Facultad Regional Córdoba, M. M. López esquina Cruz Roja Argentina, Ciudad Universitaria (5016ZAA), Córdoba, Argentina. E-mail: moniabraham5@gmail.com 
correctamente al $64,6 \%$ y $74 \%$ de los adolescentes con alta y baja exposición a música a través de RPM. Este cuestionario puede ser utilizado para detectar adolescentes que presentan una escucha riesgosa y para desarrollar estrategias para promover conductas de protección.

Palabras clave: reproductores personales de música, percepción de riesgos, percepción de beneficios, instrumento, adolescentes

Traditionally, researchers have given more attention to risk behaviors related to the illegal activities of adolescents, such as the consumption of alcohol under the age of 18, driving after drinking and substance abuse, or traditional risk behaviors, such as sexual risk practices and aggressive behavior. However, adolescents are involved in other socially acceptable activities which can lead to damage. The behavior of listening to music at high sound level with a personal music player (PMP) has become a frequent activity among adolescents of all socio-economic levels (McNeill, Keith, Feder, Konkle, \& Michaud, 2010; Vogel, Brug, Van der Ploeg, \& Raat, 2011), which is positively correlated with some risk behaviors, such as smoking, drinking alcohol, using drugs, dropping out of school, and going to discos (Bohlin \& Erlandsson, 2007). Based on this, the last decades have seen an increase in the number of studies in the field of public health aimed at finding the auditory effects of exposure to non-occupational noise in adolescents' activities in which music is played at high sound levels (Ameye, Eziyi, Adekunle, Obasi, \& Amusa, 2016; Colon et al., 2016; Jiang, Zhao, Guderley, \& Manchaiah, 2016; Twardella et al., 2017).

It is important to note that music is a pervasive element of today's society and it is linked in a distinct way to the young. In contemporary society, everything related to the young is defined through music, which represents for the adolescent a natural part of the process of searching for their own identity and, in turn, plays a significant role in their social development, becoming a central aspect of the group identity (Hormigos \& Martín Cabello, 2004). As a result, music is the most important cultural consumption by young people (Wortman, 2001). This act of listening to music has been increased in recent years, mainly because of technological development, which has made it possible to listen to music, not only in times specifically intended for this purpose, but also when carrying out many other activities.

The activities most chosen by adolescents linked to music are going out to discos, dancing rooms, and live performances, listening to music at home, taking part in music groups, and using PMP (Biassoni et al., 2011; Biassoni, Serra, Pérez Villalobo, Joekes, \& Yacci, 2008).

The sound levels young people are often exposed to have increased in parallel with technological progress, which allow the emergence of increasingly powerful devices in terms of their sound emission. This can probably explain the inverse relationship that has been observed between technological progress and hearing conservation (Biassoni et al., 2011).

Various international organizations have expressed their concern about the long-term effects of exposure to music at high noise levels in young people and warn about the significant worldwide increase of noise-induced hearing loss (NIHL) at an increasingly early age (Folmer, Griest, \& Martin, 2002; National Institutes of Health, 2000; Scientific Committee on Emerging and Newly Identified Health Risks [SCENIHR], 2008). On the other hand, the World Health Organization (2015) considers hearing loss from excessive exposure to noise to be one of the most frequent irreversible diseases, especially among young people. It stresses the importance of early detection of such disorders and states the need for implementing educational strategies aimed at the prevention and promotion of auditory health.

In relation to PMPs, the most often used by young adults are the mobile phone (Sulaiman, Seluakumaran, \& Husain, 2013) and MP3 players, which are widely used to listen to music, allowing long-time listening, while also having an increased average output capability (Serra et al., 2014). In terms of auditory health, the danger posed using such devices can be attributed to the amount of sound energy reaching the listener's eardrums and the length of exposure to the sound stimulus, that is, the effect of noise is based on the total exposure time and sound intensity (level measured in decibels; International Organization for Standardization [ISO], 1990; SCENIHR, 2008). When these devices are used in noisy surroundings, such as public spaces and transportation, users tend to turn up the volume 
to hear more clearly, which increases the amount of noise immission that reaches the inner ear (Levey, Levey, \& Fligor, 2011; Serra, Biassoni, Ortiz Skarp, Serra, \& Joekes, 2007).

Recent studies on the use of PMPs by adolescents revealed that young people are unworried about hearing loss, compared to other health problems (Quintanilla-Dieck, Artunduaga, \& Eavey, 2009) and that they use dangerous patterns that can progressively lead to permanent hearing impairment. When using PMPs, adolescents are likely to engage in risky listening behaviors and, furthermore, are unlikely to seek protection (DelGiacco \& Serpanos, 2015; Vogel, Verschuure, van der Ploeg, Brug, \& Raat, 2009). A longitudinal study developed in Argentina with adolescents of public and private schools inquired about audiological, acoustic, and psychosocial variables involved in the exposure to music at high sound levels. In the audiological aspect, the results showed a decrease in the auditory thresholds in all the adolescents assessed after the fourth year of the study (Biassoni et al., 2011). In the acoustic aspect, sound level assessments during the use of PMPs (between 83 and $105 \mathrm{dBA}$ ) revealed noise levels that exceeded those allowed by international laws (ISO, 1990) on the prevention of occupational risks (Serra et al., 2007). Despite the lack of non-occupational noise legislation, the SCENIHR (2008) defined restrictive criteria for the use of PMPs, in which one hour per day at a noise level $>89 \mathrm{dBA}$ is considered a potential health risk. Therefore, the risk of NIHL in adolescents from unsafe PMPs use is a legitimate public health concern that calls for attention (Colon et al., 2016).

To understand this phenomenon, the concept of teenager risk has gained significant importance as the behaviors or situations to which adolescents and young people are exposed can lead to developmental damage, affect their potentialities, and impair their health and well-being (Jessor, 1991).

In the literature, different theoretical approaches have been developed to explain adolescent risk behaviors, within the framework of the risk-taking process. Risk taking is defined as the participation in behaviors that are associated with some probability of undesired results (Boyer, 2006). In general terms, there have been four major theoretical and research perspectives that make important contributions to the explanation of risk behaviors in adolescence: (a) the cognitive perspective, which has focused on the development of the decision capacity that potentially underlies risk taking, including the perception of risks and benefits of a potentially hazardous situation (Beyth-Marom \& Fischhoff, 1997; Furby \& Beyth-Marom, 1992); (b) the affective-emotional perspective, that highlights the role of emotions and affection in decision-making and the skills of emotional regulation (Byrnes, 1998; Byrnes, Miller, \& Reynolds, 1999); (c) the psychobiological perspective, which analyzes the neurological and biochemical bases of cognitive and affective processes of risk taking (Steinberg, 2004, 2007, 2008); and, finally, (d) the research on social development, that emphasizes on factors such as the relationship between parents and children, parenting strategies, and the influence of peers in the emergence of risk taking tendency (Bronfenbrenner \& Morris, 1998). From the latter perspective, three explanatory models are highlighted: (a) diffusion of innovations theory (Rogers, 2002; Valente \& Fosados, 2006), which is a theory designed to address how and why new programs and ideas are used among diverse populations, i.e., it describes the process by which an innovation, defined as a practical idea or objective perceived as new by an individual, is communicated through certain channels over time to members of a social system; (b) psychological reactance theory (Brehm, 1966), which was specifically formulated to address the human needs for autonomy, self-determination, and effectance (three factors of great concern for adolescents as they approach adulthood), has provided researchers with a particularly useful framework for understanding adolescent's negative reactions to several prohibitions (Miller, Burgoon, Grandpre, \& Alvaro, 2006); and, finally, (c) the economic behavior theory, which states that reinforcement allows to explain different behaviors, both animal and human, framed in the conduct of choice, where the agencies make decisions on the basis of the environmental conditions that are established in a given time.

According to Boyer (2006), throughout the history of psychological research, the cognitive perspective has been the most eminent approach to the study of the risk-taking. From this perspective, risk taking has been explained by focusing on adolescents' perceptions of the level of risk and benefits associated with risk behaviors (Boyer, 2006). Adolescents tend to experience risky situations even having information about the negative consequences of such actions. This suggests that the knowledge about the damage that engaging in risk behaviors may have in health is not enough to protect 
adolescents from such behaviors, that is, the perception of risk alone is insufficient to predict behavior. Some authors suggest that benefits also derive from risk behaviors. These benefits act as positive reinforcers, associated, for example, to the pleasure of getting involved in new experiences and the satisfaction of gaining greater status among its peer group (Gullone, Moore, Moss, \& Boyd, 2000). As a result, to understand adolescent risk taking, both perceptions need to be included in a comprehensive model (Halpern-Felsher, Biehl, Kropp, \& Rubinstein, 2004). For example, in one of the first studies on risk perception, Benthin, Slovic, and Severson (1993) found that adolescents who took part in risky activities tended to perceive them as more beneficial and less risky than those who did not. In this study, the authors have shown that the outcome expectancies of potential positive and negative consequences are related to the participation in a variety of risky activities. Later studies showed that benefit perception has greater predictive power in risky sexual behaviors (Parsons, Halkitis, Bimbi, \& Borkowski, 2000) and the use of alcohol (Goldberg, Halpern-Felsher, \& Millstein, 2002), illegal drugs (Parsons, Siegel, \& Cousins, 1997), and smoking (Halpern-Felsher et al., 2004).

Gullone and Moore (2000) describe four major groups of risks that adolescents experience: thrillseeking, rebelliousness, recklessness, and antisociability. Risk behaviors due to the search for emotions were associated with those behaviors that are dangerous for young people but socially acceptable, such as practicing dangerous sports, experiencing sexuality and PMPs-related behavior.

Therefore, it is important to know the considerations that adolescents make of their own listeningto-PMPs behavior and the positive and negative consequences of this. To accurately assess them, reliable assessment instruments are needed.

It has been observed that self-report measures constitute one of the most appropriate assessment procedures to measure the interpersonal functioning of adolescents (Inglés, Méndez, Hidalgo, Rosa, \& Estévez, 2003) and risk behaviors in particular (Brener, Billy, \& Grady, 2003), which makes it possible to estimate cognitive and emotional aspects of difficult access to external evaluation, get a lot of information with a minimum investment of time, and express themselves through scores that facilitate the interpretation of the results without the need for inferences, introducing appropriate psychometric properties (Fernández-Ballesteros, 2007).

The literature on adolescent risk behaviors refers to the development of a variety of instruments of this type to measure different behaviors and the frequency of participation in them, evaluating the perception of the risks of such participation. For example, the Cognitive Assessment of Risky Events Questionnaire (CARE; Fromme, Katz, \& Rivet, 1997) was developed to assess the expectations of results of the participation in risk activities, such as alcohol consumption, drugs, sex, and aggression, as well as activities related to school, work, and sport. Another tool that evaluates the concept of adolescent risk is the Risk Involvement and Participation Scale (RIPS; Siegel et al., 1994), which determines participation in a set of behaviors, perceived benefits of participation in these behaviors (perceived benefits), and perceived risks of behaving in this way (perceived risks), in six activities: alcohol, illegal drugs, sex, male stereotypic behaviors, socially acceptable behaviors, and imprudent behaviors.

More specifically, the Adolescent Risk-Taking Questionnaire (ARQ; Gullone et al., 2000), evaluates the frequency of participation in risk behaviors. This instrument was adapted by Bohlin and Erlandsson (2007), who added items related to exposure to high-level noises (listening to music, visiting rock concerts, going to night clubs, taking part in motor sports), in order to analyze the relationship between self-exposure to high noise levels and the participation of adolescents in situations of elevated risk, in a more traditional sense (e.g., smoking and alcohol consumption).

While these technical developments made an important contribution to the measurement of the behavior and psychological constructs found as significant by the literature, these scales and instruments do not inquire into the specific behavior of the exposure to PMPs in adolescents. Another limitation of these instruments is the method of assessment: a series of behaviors are listed and the teenager must answer on a Likert-type scale about them (i.e., the level of participation in the behavior). The information obtained is useful, although it is partial, because it does not make it possible to answer the question What are the specific risks and benefits that are perceived from a particular risk behavior? 
Given the importance of music in the lives of adolescents and young people and on the basis of the absence of tools to measure the phenomenon available in the literature, the objective of the present study was to develop an instrument that would make it possible to evaluate the perception of positive consequences (benefits) and negative consequences (risks) of exposure to RPM in adolescents and, in this way, to have a valid instrument that allows the realization of systematic studies related to exposure to RPM, covering the gap that exists at the time in this field, which in turn will allow a better understanding of the phenomenon and will facilitate the development of strategies for the promotion of behaviors of protection against the risky behavior of listening to music on PMPs in adolescents.

\section{The Study}

The process of construction and validation of the instrument was performed on a three-phase cycle. In the first phase, in-depth interviews were conducted with adolescents to generate relevant items on the positive and negative consequences of listening to music at high sound levels on PMPs. In the second phase, the first pool of items was reviewed by test-making experts and administered to a pilot sample to assess the clarity, intelligibility, and appropriateness of each of the items. In the third phase, the items selected in the earlier phase were administered to a sample of adolescents, in order to assess its predictive validity and examine the structure of the questionnaire, using exploratory factor analysis (EFA) and confirmatory factor analysis (CFA) .

For the conformation of the samples of all the phases, an accidental sampling (Grasso, 1999) was carried out, given that the administration of the instruments was conducted only in those establishments where both the permission of the authorities and the consent of the parents were obtained.

For the administration of the instruments, authorization to Dirección General de Educación Secundaria (General Board of Secondary Education) of the cities of Córdoba and Rafaela was asked. The Board assessed whether the study met the National Act \#25.326, regulating the protection of personal information of the participants, the privacy of the data collected, and its use only for academic and scientific purposes. Once the confirmation of compliance with the Act was granted, permission was asked to the directors of each school where the study would be carried out. To obtain consent for the participation of adolescents, their parents or guardians were contacted by a notice setting out the reasons, importance, and consequences of their children's participation in the study, so that they could express their disagreement (or refuse permission) if they wanted (passive consent method). Thus, adolescents who did not have permission were excluded. The administration of the instruments was carried out in the classroom where classes are taught, in small groups to ensure proper management of the group.

\section{Phase 1: Item Pool Development}

Method. To obtain the first pool of items two qualitative procedures were carried out: (a) revision of recent literature on adolescents' perceptions of the risk and benefit level associated with risky behaviors (e.g., Boyer, 2006) and (b) conducting individual interviews with adolescents to obtain the necessary material to construct the items and to later write them. Based on the data obtained in this phase, the first pool of items was made up, on which the questionnaire was built.

Participants. In two schools (one public and one private) of the city of Córdoba, Argentina, 43 adolescents from $2^{\text {nd }}$ to $6^{\text {th }}$ grade (Argentine education system, equivalent to $9^{\text {th }}$ to $12^{\text {th }}$ year of regular instruction) of both sexes, aged 13 to 18 years, were selected randomly (54\% women; mean age, 15.32 years, $S D=1.75$ ).

Instrument. Open, in-depth interviews were conducted individually to investigate the perceived positive consequences (benefits) and negative consequences (risks) of listening to music on PMPs in adolescents. This technique was thought to generate items relevant to the variables in the study. The adolescents had to respond to the following open questions: (a) What are the benefits or positive consequences of listening to music on personal music players (such as MP3 players, cell phones, etc.) 
at high sound levels? and (b) What are the risks or negative consequences of listening to music on personal music players at high sound levels?

Procedure. The interviews were conducted at the schools the students attended and during normal school hours. They were conducted by the authors of these study (one interviewer and one participant observer). The participants' answers were recorded by note-taking.

Data analysis. An analysis of the data gathered from the records was carried out. Two predetermined categories were used according to the conceptual definition of risk perception and benefits perception described above: the positive consequences (or benefits) perceived and the negative consequences (or risks) perceived of listening to music on PMPs at high sound levels by adolescents. During a preliminary analysis, a descriptive summary of the content was constructed, together with the exact statements and conversation excerpts that were considered key. Subsequently, during the second level of analysis, the items were written based on a theoretical model from which the information was interpreted.

Results. Sixty-nine items were written for the global scale (41 positives and 28 negatives). Some conventional guidelines were considered when writing the items: (a) the items should be consistent with the purpose of the test, (b) excessively long items should be avoided, (c) complex and ambiguous sentences should be avoided, (d) statements with double negatives should be avoided, (e) extreme expressions (e.g., never, always, all) should be avoided, and (f) language should be used that is appropriate for the maturity and education level of the target population (Osterlind, 1990).

\section{Phase 2: Content Validity}

In this phase, the following elements were used: (a) opinions of experts to prove whether the items written were a representative sample of the construct of which some inference is to be made, and (b) cognitive interviews, to find the understanding process among adolescents on each of the items.

Experts judgement. The goal of this study was to establish a consensus among the judges on the degree of congruence between the questionnaire items and the specific descriptions of each domain that the instrument purports to measure.

Method. The items written in the earlier stage were reviewed by expert judges to evaluate their semantic clarity and grammatical correctness, appropriateness to the comprehension level of the target population, and each item's congruence with the construct measured.

Participants. A group of six judges was convened: three of these judges were experts in acoustics and psychoacoustics and the other three, specialists in item writing and test construction (psychometricians).

Instrument. To establish a consensus about the degree of congruence between items and specific descriptions of the content domain, the acoustics and psychoacoustic experts received a form having 69 items and the conceptual definition of the scale's two domains with which they were asked to classify each item in the proper domain. The psychometric experts assessed how well the items were written, by considering relevance, syntactic and semantic clarity, and how proper they were for the intended adolescent population (Osterlind, 1990). A score of 10 showed high quality, and a score of 1 showed low quality and an explicit suggestion of non-inclusion. A space was also offered where the judges could give observations that may be useful for the investigation.

Data analysis. Agreement between examiners was estimated using the intraclass correlation coefficient (ICC). This ratio is considered more proper than the Pearson correlation coefficient, because the latter shows the strength of the linear association between both assessments but not the agreement between judges. 
Results. The study of agreement between psychoacoustic experts yielded an ICC of 0.83 , with $95 \%$ CI $(0.76,0.89)$, which was considered adequate. For item quality, the agreement between psychometric experts yielded an ICC of 0.14 with $95 \%$ CI $(0.01,0.30)$. Because of lack of agreement between the judges, each item was henceforth reviewed separately. To this end, only items with a score $\geq 6$ per judge were selected. Based on these criteria, 27 statements were eliminated. Following the judges' suggestions, some items were rewritten using simpler terminology and only those with the highest score in conceptual clarity were kept.

\section{Cognitive interviews.}

Method. This qualitative method consisted of evaluating the clarity, comprehensibility, appropriateness, and cultural importance of each item.

Participants. A sample of 21 students (9 male, 12 female, mean age $=15.47, S D=1.53$ ) was used. This sample was selected through the snowball sampling procedure.

Instrument. Considering the results obtained from the analysis of item quality and the judges' suggestions, cognitive interviews were conducted to identify potentially problematic items. Each interviewee received a questionnaire with the 42 items selected in the previous phase. They were asked to read each item and mention what they understood and how they would describe, in their own words, the behavior indicated in the item. Interviews were conducted using the think-aloud technique, in which the interviewee verbalized his thoughts while completing the questionnaire (Collins, 2003). Using this technique, the subject's comprehension of the questionnaire was explored and mistakes, inconsistencies, or terms that were not very clear were found.

Procedure. Interviews were recorded via note-taking by the authors of the present study.

Data analysis. The adolescents' mental processes when answering the questions on the questionnaire were analyzed, and difficulties, such as the phrasing of the items or format of the questionnaire, were detected.

Results. Items with idiomatic expressions with which the population was unfamiliar were reviewed and replaced with everyday terminology, and some redundant items were omitted. The resulting version of the scale had 35 items.

\section{Phase 3: Construct Validity, Criterion-Related Validity, and Internal Consistency}

Method. To further refine the item pool and to offer a preliminary analysis of the potential factor structure of the questionnaire, EFA and CFA were used to examine the items within each of the broad domains. Its internal consistency and the predictive validity for the level of exposure to music from PMPs was also analyzed.

Participants. Participants were adolescents enrolled in five (two public and three private) high schools in the cities of Córdoba and Rafaela, Argentina. The sample consisted of 630 students of both sexes $(62.2 \%$ female), aged $13-18$ years $(M$ age $=15.35$ years, $S D=1.50)$ and enrolled in public $(62 \%)$ and private (38\%) educational institutions. Considering the characteristics of the institutions and the students that took part in the study (the latter belonging to families of skilled workers, largeproduction farmers, professionals, and local merchants), as well as the classification given by the Instituto Nacional de Estadística y Censos (National Institute of Statistics and Censuses), the sample was representative of upper-middle and lower-middle socio-economic classes.

\section{Instruments.}

Adolescent Perceived Risks and Benefits of Exposure to Music from PMPs Questionnaire. This questionnaire was composed of 35 items grouped into two scales (Risk Perception [RP] and Benefit 
Perception [BP]) and applied following the first stage of item construction. Participants rated each item (e.g., "Listening to music from personal music players, helps me get my mind off of things") on a 5-point scale, ranging from 1 (totally disagree) to 5 (totally agree).

Questionnaire of Adolescents' Exposure to Noise coming from PMPs (Biassoni et al., 2011). This questionnaire was constructed ad hoc for this study to measure predictive validity and assess the levels of noise exposure from PMPs in adolescents. The dimensions that it explored are the frequency of use (days per week), duration of use (hours per day), and listening sound level or volume (on a scale of 1 to 10). The global score is obtained with the following formula: [(hours per day + volume) $\mathrm{x}$ days per week].

Procedure. Despite not having information on the recruitment rate (how many students, from those invited, turned in the informed consent forms), most parents gave their permission. Only 14 of these students, however, declined to take part.

The questionnaires were administered jointly during the normal hours of the school day and lasted for 15 minutes. Teachers stayed in the classroom to help watch the behavior of the students. Efforts were taken to seek the cooperation of students and the voluntary nature of their participation was emphasized. The researcher, who was one of the authors of this study, offered detailed instructions about how to complete the questionnaires and students had the opportunity to ask questions.

Data analysis. The routine Missing Values Analysis of SPSS version 19.0 was used to assess the pattern of missing values (Tabachnick \& Fidell, 2007). Indices of skewness and kurtosis were calculated for each item. Subsequently, the sample was divided into two parts at random. The first half was selected for the analysis of the potential factor structure of the questionnaire. For this study, the items were analyzed using EFA (polychoric correlations, unweighted least squares [ULS] extraction, and oblique Promin rotation). This analysis was performed using FACTOR 9.2 software (Lorenzo-Seva $\&$ Ferrando, 2013). The number of factors extracted was based on the results of a parallel analysis using marginally bootstrapped samples (Horn, 1965) and Hull method for selecting the number of common factors (Lorenzo-Seva, Timmerman, \& Kiers, 2011). The second half was reserved to conduct the CFA. Mplus 6.12 (Muthén \& Muthén, 2010) software was used and robust weighted least squares (robust WLS) was used to estimate the model. This method better suits factor analyses with ordinal indicators. Multiple indices of the goodness of fit were employed to evaluate the fit of the model: The Tucker-Lewis index (TLI), the Bentler-Bonett comparative fit index (CFI), the root mean square error of approximation (RMSEA), and weighted root mean square residual (WRMR). CFI and TLI values equal or greater than 0.90, RMSEA values between 0.05 and 0.08 , and WRMR values below 1.00 (Yu, 2002) show an excellent or acceptable model fit. Subsequently, an EFA was performed with the total sample to estimate factor scores.

The study of internal consistency of each scale was performed using reliability of rotated factors coefficient (Mislevy \& Bock, 1990) and each item's bivariate Pearson correlation with the subscale was examined.

Finally, a multiple discriminant analysis was performed using RP and BP variables as predictors of differences between the variables, according to the level of exposure to music from PMPs. This analysis was used to assess the predictive capacity of the Adolescent Perceived Risks and Benefits of Exposure to Music from PMP Questionnaire to explore differences between the variables according to the level of exposure to music from PMPs, considering the frequency of the music players' use (in days per week), duration of exposure (in hours per day), and listening sound level or volume (on a scale of 1 to 10). The purpose of this analysis was to find the linear combination of the independent variables that best distinguished (discriminated) the groups. Once found, this combination (i.e., the discriminant function) could be used to classify new cases. For the present analysis, the two factors RP and BP were used as independent variables, and two extreme categories (25\% highest and $25 \%$ lowest) of music exposure from PMPs served as the dependent variables. Statistical methods for the determination of the cutting point aimed at data are based on the calculation of quantiles. A procedure widely used to set reference intervals of analytical tests is based on selecting the values of two percentiles centered around the median of the distribution, specifically the 25 and 75 percentiles, when the objective of the study is to 
find the cutoff point to guide decision-making (Fuentes Smith, 2013). A stepwise procedure was used, in which the variables were input according to their weight in the discriminant function.

\section{Results.}

Data preparation. Each of the 35 items of the questionnaire had some missing data, but no item had $>5 \%$ missing (range: $3.1 \%-4.7 \%$ ). As this percentage was small, it was decided to impute data for a measure of central tendency (mode) of the complete answers of a participant in the same scale. This method offers a conceptual attractive balance of accuracy and simplicity in cases of lost by not answering any item (Shrive, Stuart, Quan, \& Ghali 2006). Twenty-four items presented skewness and kurtosis values between +1 and -1 , which are considered excellent in the literature (George \& Mallery, 2011). Six items presented acceptable indices of skewness and kurtosis, and five, unacceptable indices (values greater than \pm 2.0 ). The latter ones were excluded from later analyses (all the items that were eliminated belonged to the PB factor). In these items, answers were found to be concentrated in the options Agree and Strongly agree (accumulated frequency between 86.9\% and 96.7\%), which is what caused these extreme skewness and kurtosis values. In all the items, it was verified that the participants have used at least three of the five answer choices. Twenty-three cases were excluded by using only two answer choices. Subsequently, $50 \%$ of the cases were randomly selected for EFA and CFA.

Exploratory factor analysis. An EFA was performed on the 30 remaining items using a robust ULS estimator. The results of the parallel analysis and Hull method suggested that two factors should be extracted. As a rule of thumb, a factor loading value of 0.32 (i.e., $10 \%$ of the variance; Tabachnick \& Fidell, 2007) was used as a cutoff when making decisions about the retention or exclusion of items. Items that loaded on more than one factor and items that did not load on any factor were eliminated. Following these criteria, a total of 19 items were kept. Therefore, the 19 items were factor-analyzed again using ULS method with two factors, keeping the same aforementioned criteria to eliminate items from the factor structure. A theoretically meaningful two-factor solution that explained $37 \%$ of the shared variance was obtained. The two factors, with their respective items, are displayed in Table 1.

The Benefit Perception subscale (10 items) presented a reliability coefficient of 0.84 and the RP subscale (9 items), 0.78. Item-to-scale-total correlations were 0.36-0.60 between the items on the BP subscale (Table 2) and 0.33-0.53 between the items on the RP subscale (Table 3).

Confirmatory factor analysis. The model proposed two inter-correlated factors in which items load on their individual subscale factor.

The hypothesized measurement model offered an overall acceptable-to-poor fit to the data, $\mathrm{CFI}=0.88, \mathrm{TLI}=0.87, \mathrm{WRMR}=1.297, \mathrm{RMSEA}=0.07,90 \% \mathrm{CI}=0.06,0.08$. Post hoc model modifications were then conducted to improve the fit of the model. In this case, the modification indices indicated apparent content that overlapped between three pairs of items: item 1 asks if the interviewee listens to music from PMPs at high sound levels because "it's fun" [for him/her], whereas item 4 asks if the interviewee listens to music because "It motivates me [him/her] to do things." These items have a clear conceptual relation. The same situation occurs in other two pairs of items "It makes me forget my problems" (item 5) versus "It helps me get my mind off of things" (item 26) and "It blocks communication with others" (item 20) versus "It prevents me from hearing people" (item 34). Therefore, the parameters of covariance between the errors were also included in the model. Also, the items "It distracts me from the surrounding noise" (item 17), "When I listen to music, nobody bothers me" (item 18), and "It is deafening" (item 19) were removed, because the modification indices indicated that they were bi-dimensional and that, when removing them, the data adjustment improved. The revised measurement model offered an overall acceptable fit to the data, CFI $=0.92$, TLI $=0.90$, WRMR $=1.139$, RMSEA $=0.06,90 \% \mathrm{CI}=0.05,0.07$ and the two-factor model with eight items for BP and eight items for RP (Figure 1). The factor loadings varied between 0.48 and 0.77 for the BP factor and from 0.52 and 0.67 for the RP factor. 
Table 1

Configuration Matrix with Factor Weights for the 19 Final Items

\begin{tabular}{|c|c|c|}
\hline \multirow{2}{*}{$\begin{array}{c}\text { Spanish items } \\
\text { (Translation) }\end{array}$} & \multicolumn{2}{|c|}{ Factor } \\
\hline & 1 & 2 \\
\hline $\begin{array}{l}\text { 1. Me divierte } \\
\text { (It's fun for me) }\end{array}$ & -0.16 & 0.45 \\
\hline $\begin{array}{l}\text { 2. Me hace sentir acompañado } \\
\text { (It makes me feel like I am not alone) }\end{array}$ & -0.01 & 0.43 \\
\hline $\begin{array}{l}\text { 3. Me relaja } \\
\text { (It relaxes me) }\end{array}$ & -0.15 & 0.57 \\
\hline $\begin{array}{l}\text { 4. Me motiva para hacer cosas } \\
\text { (It motivates me to do things) }\end{array}$ & -0.10 & 0.46 \\
\hline $\begin{array}{l}\text { 5. Me hace olvidar de los problemas } \\
\text { (It makes me forget my problems) }\end{array}$ & -0.02 & 0.63 \\
\hline $\begin{array}{l}\text { 6. Me provoca emociones agradables } \\
\text { (It evokes positive emotions in me) }\end{array}$ & 0.03 & 0.66 \\
\hline $\begin{array}{l}\text { 7. Permite expresar mis emociones } \\
\text { (It allows me to express my emotions) }\end{array}$ & 0.03 & 0.70 \\
\hline $\begin{array}{l}\text { 8. Me ayuda a pensar en otra cosa } \\
\text { (It helps me get my mind off of things) }\end{array}$ & 0.08 & 0.67 \\
\hline $\begin{array}{l}\text { 9. Me molesta para realizar mis actividades } \\
\text { (It keeps me from doing my activities) }\end{array}$ & 0.32 & -0.22 \\
\hline $\begin{array}{l}\text { 10. Me impide pensar claramente } \\
\text { (It prevents me from thinking clearly) }\end{array}$ & 0.32 & 0.00 \\
\hline $\begin{array}{l}\text { 11. Produce molestias en mi audición } \\
\text { (It causes me to have hearing problems) }\end{array}$ & 0.49 & -0.06 \\
\hline $\begin{array}{l}\text { 12. Impide concentrarme para estudiar } \\
\text { (It distracts me from studying) }\end{array}$ & 0.45 & -0.06 \\
\hline $\begin{array}{l}\text { 13. Interfiere la comunicación con los demás } \\
\text { (It blocks communication with others) }\end{array}$ & 0.61 & 0.20 \\
\hline $\begin{array}{l}\text { 14. Puede provocar algún daño en mi audición } \\
\text { (It can cause some damage to my hearing) }\end{array}$ & 0.66 & 0.04 \\
\hline $\begin{array}{l}\text { 15. Me impide escuchar a la gente } \\
\text { (It prevents me from hearing people) }\end{array}$ & 0.58 & 0.12 \\
\hline $\begin{array}{l}\text { 16. Me produce dolor de cabeza } \\
\text { (It gives me a headache) }\end{array}$ & 0.49 & -0.00 \\
\hline $\begin{array}{l}\text { 17. Me aísla del ruido exterior } \\
\text { (It distracts me from the surrounding noise) }\end{array}$ & 0.17 & 0.42 \\
\hline $\begin{array}{l}\text { 18. Hace que nadie me moleste cuando escucho música } \\
\text { (When I listen to music, nobody bothers me) }\end{array}$ & -0.02 & 0.39 \\
\hline $\begin{array}{l}\text { 19. Me aturde } \\
\text { (It's deafening) }\end{array}$ & 0.51 & -0.24 \\
\hline
\end{tabular}


Table 2

Coefficients of Item-Total Correlation and Cronbach's Alpha if the Item of the Benefits Perception Subscale Is Removed

\begin{tabular}{lcc}
\hline \multicolumn{1}{c}{ Item } & Item-total correlation & $\begin{array}{c}\text { Cronbach's alpha if } \\
\text { the item is removed }\end{array}$ \\
\hline 1. Me divierte & 0.427 & 0.809 \\
2. Me hace sentir acompañado & 0.432 & 0.808 \\
3. Me relaja & 0.572 & 0.794 \\
4. Me motiva para hacer cosas & 0.457 & 0.805 \\
5. Me hace olvidar de los problemas & 0.603 & 0.790 \\
6. Me provoca emociones agradables & 0.489 & 0.803 \\
7. Permite expresar mis emociones & 0.574 & 0.793 \\
8. Me ayuda a pensar en otra cosa & 0.497 & 0.801 \\
17. Me aísla del ruido exterior & 0.355 & 0.813 \\
18. Hace que nadie me moleste cuando escucho música & 0.407 & 0.811 \\
\hline
\end{tabular}

Table 3

Coefficients of Item-Total Correlation and Cronbach's Alpha if the Item of the Risks Perception Subscale Is Removed

\begin{tabular}{lcc}
\hline \multicolumn{1}{c}{ Item } & Item-total correlation & $\begin{array}{c}\text { Cronbach's alpha if } \\
\text { the item is removed }\end{array}$ \\
\hline 9. Me molesta para realizar mis actividades & 0.414 & 0.777 \\
10. Me impide pensar claramente & 0.355 & 0.784 \\
11. Produce molestias en mi audición & 0.534 & 0.765 \\
12. Impide concentrarme para estudiar & 0.463 & 0.773 \\
13. Interfiere la comunicación con los demás & 0.455 & 0.773 \\
14. Puede provocar algún daño en mi audición & 0.509 & 0.767 \\
15. Me impide escuchar a la gente & 0.502 & 0.769 \\
16. Me produce dolor de cabeza & 0.504 & 0.767 \\
19. Me aturde & 0.522 & 0.767 \\
\hline
\end{tabular}

Criterion-related validity. A statistically significant discriminant function was obtained, with a Lambda $(\Lambda)$ of 0.81 . Bartlett's V called for the rejection of the null hypothesis that the two groups compared had identical means in the discriminant variables, $\chi^{2}(2, N=596)=62.12, p<0.001$.

In the first step of the analysis, the BP scale distinguished between the groups with less and more noise exposure, $F(1,292)=57.56, p<0.001$, with $\mathrm{RP}$ increasing this difference even more in step 2 , $F(2,291)=34.62, p<0.001$. Examination of the standardized canonical discriminant function coefficients and centroids $(\bar{d})$ obtained in the discriminant analysis revealed a profile of adolescents with high BP and low RP mainly associated with the high noise exposure level group $(\bar{d}=0.86)$ and another with low BP and high RP associated with the low noise-exposure level group $(\bar{d}=-0.42)$. When both scales were used as predictors, the percentage of cases that were correctly classified in the separate groups was $69.4 \%$, a $19.4 \%$ improvement over the earlier group probability (50\%). The classification of adolescents by group revealed that the highest classification percentage, $74 \%$, corresponded to the group with the most noise exposure, followed by $64.6 \%$ for the group with the least noise exposure. 


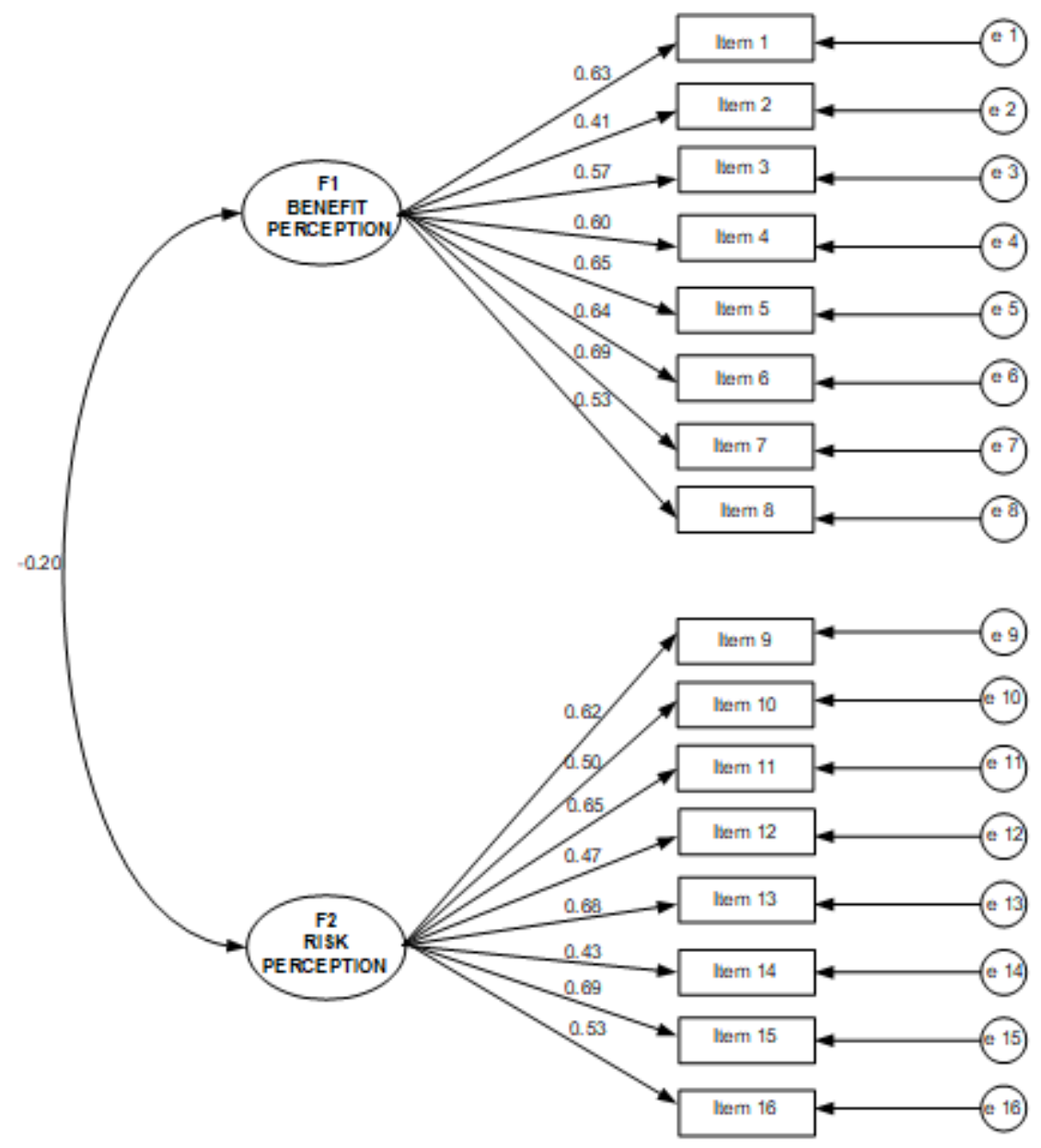

Figure 1. Confirmatory factor analysis of the Perceived Risks and Benefits of Personal Music Players Questionnaire. All path coefficients were statistically significant, $p<0.05$.

\section{Discussion}

A growing tendency has been seen for adolescents to expose themselves to non-occupational noise during leisure activities, particularly associated with the presence of music at high sound levels. The use of PMPs (e.g., MP3 players, cell phones, and iPods) is one of the most common activities associated with exposure to non-occupational noise (Bohlin \& Erlandsson, 2007; Morata, 2007). If necessary protective measures are not taken, then daily use for several hours and at a high volume could eventually lead to a NIHL (Vogel et al., 2009). Accordingly, current research considers this a health risk behavior and has shown that it can be a social and public health problem that needs the development and implementation of strategies to prevent risky behaviors and promote auditory health (SCENIHR, 2008; Vogel et al., 2011).

The purpose of the present study was to develop and validate test items to assess adolescent perceived positive consequences (benefits) and negative consequences (risks) of listening to music on PMPs. The 16 final items of the Adolescent Perceived Risks and Benefits of Exposure to Music from PMP Questionnaire reflects adolescents' perceptions of the levels of risk and benefit associated with risky behaviors and presents acceptable psychometric properties. Every factor's item analysis showed evidence of content validity, internal consistency, and criterion validity. The questionnaire has allowed discrimination between adolescents with high and low exposure to music from PMPs, using a multiple 
discriminant analysis, and its use could be extended to detecting adolescents who show risky listening habits according to their RP and BP. Likewise, adolescents with high exposure perceived greater benefits, while adolescents with lower exposure perceived greater risks. These discoveries suggest that the group of adolescents who are most exposed to music live in the moment, with disregard for future consequences. This willingness to take on more long-term risks and short-term benefits has been well-documented comparing other risky behaviors (Gullone et al., 2000; Halpern-Felsher et al., 2004). Similar conclusions were drawn in a study by Vogel et al. (2011) in Dutch adolescents. Adolescents who were more exposed to their PMPs were more concerned with maximizing immediate benefits and more affected by the immediate effects, such as "escaping" through their music, than potential negative long-term consequences. In addition, through the items of this instrument, certain immediate risks or extra-auditory effects can be estimated, such as physiological, psychological, and social problems, for example, annoyance, restlessness, anxiety, fear, shock, alarm, disturbance of the short-term memory, loss of alert, disturbance of the teaching and learning process, and loss or reduction of the intelligibility of the spoken word (Miyara, 2005, September/October). With regard to the disturbance in the communication, this is caused by the presence of a high-intensity sound while holding a conversation, which causes interference and masks the language, making it difficult to understand. Nonetheless, many of these effects are subjective, therefore, depend on the importance that the person gives to the sound source, the adaptive capacity, and the individual sensitivity, rather than the quality of the sound stimulus and the intensity level (Guski, 1997).

However, caution should be exercised in generalizing the present findings because of the nonrepresentativeness of the sample. Although adolescent students from both public and private school were included, explicit consideration was not given to the students' socio-economic status, a variable that should be considered in future studies. Another weakness was the discriminant analysis that used extreme groups (25\% highest and $25 \%$ lowest), based on adolescents' self-report. The use of subjective measures to estimate exposure to noise from PMPs (a questionnaire that assesses the frequency, duration, and intensity of listening) could be complemented with objective measurements that can more precisely establish the levels of noise to which adolescents are exposed when using their PMPs in different environments.

The study presented is an interesting step in the development of an instrument to assess risk and benefits of PMPs, but more research is needed, both in Argentina as well as in other countries, before the stability of the structure of the instrument and its validity can be clearly established. For example, it would be advisable to perform further studies that assess the instrument's temporal stability and contrast the instrument's validity results using item response theory. Furthermore, the evaluation of the usefulness and scope of the instrument developed is proposed for future experimental studies, particularly pre-post studies to assess the efficacy of the interventions.

The present study focused on the perceived levels of risk and benefits associated with risky behaviors (i.e., listening to music on PMPs). Numerous studies have shown the usefulness of these variables in predicting different risky behaviors (Goldberg et al., 2002; Halpern-Felsher et al., 2004; Parsons et al., 1997; Parsons et al., 2000). However, no studies in the literature have tried to explain listening to music at high sound levels on PMPs making the present study even more relevant.

The Adolescent Perceived Risks and Benefits of Exposure to Music from PMP Questionnaire constitutes an advance in the field of hearing conservation to detect adolescents with risky PMP-listening habits due to the weight given to the risks and benefits of their behavior. This questionnaire could be used to evaluate the effectiveness of educational programs to promote hearing health in adolescents. Achieving voluntary change in adolescents may be difficult when considering how important the perceived benefits are to this group of individuals who are most exposed to their PMPs. Implementing strategies that prevent PMP-induced hearing impairment through programs that promote protective behaviors in adolescents may be necessary, such as limiting daily listening time, controlling the use of PMPs in noisy surroundings (e.g., public places or public transportation), and listening at moderate levels (60\% of the PMP's maximum volume). Such strategies would be aimed at adolescents who can receive the direct benefits of this activity but through healthier habits. Because PMP use begins at an early age, health-promoting actions should begin in school-age children to 
increase their awareness of the risks of loud music (Biassoni et al., 2011). Thus, children can achieve a better understanding of healthy listening habits and learn about ways to protect their hearing before their risky listening behaviors become habits.

\section{References}

Ameye, S. A., Eziyi, J. A. E., Adekunle, A., Obasi, O., \& Amusa, Y. B. (2016). Survey of recreational noise exposure through the use of personal music players in young Nigerian adults. Nigerian Journal of Health Sciences, 16, 39-42. https://doi.org/10.4103/1596-4078.190038

Benthin, A., Slovic, P., \& Severson, H. (1993). A psychometric study of adolescent risk perception. Journal of Adolescence, 16, 153-168. https://doi.org/10.1006/jado.1993.1014

Beyth-Marom, R. \& Fischhoff, B. (1997). Adolescents' decisions about risks: A cognitive perspective. In J. Schulenberg, J. L. Maggs, \& K. Hurrelmann (Eds.), Health risks and developmental transitions during adolescence (pp. 110-139). New York, NY: Cambridge University Press.

Biassoni, E. C., Serra, M. R., Pavlik, M., Hinalaf, M., Curet, C., Pérez Villalobo, J. ... Righetti, A. (2011). Programa de conservación y promoción de la audición en la etapa adolescente: primeros resultados. In M. C. Richard \& V. Lemos (Eds.), Compendio de investigaciones actuales en psicología y ciencias afines (pp. 475-503). Buenos Aires, Argentina: Centro Interdisciplinario de Investigaciones en Psicología Matemática y Experimental.

Biassoni, E. C., Serra, M. R., Pérez Villalobo, J., Joekes, S., \& Yacci, M. R. (2008). Hábitos recreativos en la adolescencia y salud auditiva. Revista Interamericana de Psicología, 42, 257-271. Retrieved from http://www.redalyc.org/articulo.oa?id=28442208

Bohlin, M. C. \& Erlandsson, S. I. (2007). Risk behaviour and noise exposure among adolescents. Noise \& Health, 9, 55-63. https://doi.org/10.4103/1463-1741.36981

Boyer, T. W. (2006). The development of risk-taking: A multi-perspective review. Developmental Review, 26, $291-345$. https://doi.org/10.1016/j.dr.2006.05.002

Brehm, J. W. (1966). A theory of psychological reactance. Oxford, United Kingdom: Academic Press.

Brener, N. D., Billy, J. O. G., \& Grady, W. R. (2003). Assessment of factors affecting the validity of self-reported health-risk behavior among adolescents: Evidence from the scientific literature. Journal of Adolescent Health, 33, 436-457. https://doi.org/10.1016/S1054-139X(03)00052-1

Bronfenbrenner, U. \& Morris, P. A. (1998). The ecology of developmental processes. In W. Damon \& R. M. Lerner (Eds.), Handbook of child psychology: Theoretical models of human development (pp. 993-1028). Hoboken, NJ: John Wiley \& Sons.

Byrnes, J. P. (1998). The nature and development of decision making: A self-regulation model. Mahwah, NJ: Lawrence Erlbaum.

Byrnes, J. P., Miller, D. C., \& Reynolds, M. (1999). Learning to make good decisions: A self-regulation perspective. Child Development, 70, 1121-1140. https://doi.org/10.1111/1467-8624.00082

Collins, D. (2003). Pretesting survey instruments: An overview of cognitive methods. Quality of Life Research, 12, $229-238$. https://doi.org/10.1023/A:1023254226592

Colon, D. C., Verdugo-Raab, U., Alvarez, C. P., Steffens, T., Marcrum, S. C., Kolb, S. ... Twardella, D. (2016). Early indication of noise-induced hearing loss from PMP use in adolescents: A cross-sectional analysis. Noise \& Health, 18, 288-296. https://doi.org/10.4103/1463-1741.195798

DelGiacco, A. M. \& Serpanos, Y. C. (2015). Education and knowledge of noise exposure, hearing loss, and hearing conservation in college students. Contemporary Issues in Communication Science and Disorders, 42, 88-99. Retrieved from https://www.asha.org/uploadedFiles/ASHA/Publications/cicsd/2015S-Education-and-Knowledge-of-Noise.pdf

Fernández-Ballesteros, R. (Dir.) (2007). Evaluación psicológica: conceptos, métodos y estudio de casos. Madrid, Spain: Pirámide.

Folmer, R. L., Griest, S. E., \& Martin, W. H. (2002). Hearing conservation education programs for children: A review. Journal of School Health, 72, 51-57. https://doi.org/10.1111/j.1746-1561.2002.tb06514.x

Fromme, K., Katz, E. C., \& Rivet, K. (1997). Outcomes expectancies and risk-taking behavior. Cognitive Therapy and Research, 21, 421-442. https://doi.org/10.1023/A:1021932326716

Fuentes Smith, L. E. (2013). Metodología para la elección de punto de corte óptimo para dicotomizar covariables continuas. Revista Cubana de Genética Comunitaria, 7(3), 36-42. Retrieved from http://bvs.sld.cu/revistas/rcgc/v7n3/060313.pdf

Furby, L. \& Beyth-Marom, R. (1992). Risk taking in adolescence: A decision-making perspective. Developmental Review, 12, 144. https://doi.org/10.1016/0273-2297(92)90002-J

George, D. \& Mallery, P. (2011). SPSS for Windows step by step: A simple guide and reference 18.0 update (11 ${ }^{\text {th }}$ ed.). Boston, MA: Allyn \& Bacon.

Goldberg, J. H., Halpern-Felsher, B. L., \& Milltein, S. G. (2002). Beyond invulnerability: The importance of benefits in adolescents' decision to drink alcohol. Health Psychology, 21, 477-484. https://doi.org/10.1037/0278-6133.21.5.477

Grasso, L. T. P. (1999). Introducción a la estadistica en ciencias sociales y del comportamiento. Córdoba, Argentina: Universidad Nacional de Córdoba, Facultad de Filosofía y Humanidades.

Gullone, E. \& Moore, S. (2000). Adolescent risk-taking and the five-factor model of personality. Journal of Adolescence, 23, 393407. https://doi.org/10.1006/jado.2000.0327

Gullone, E., Moore, S., Moss, S., \& Boyd, C. (2000). The adolescent risk-taking questionnaire: Development and psychometric evaluation. Journal of Adolescent Research, 15, 231-250. https://doi.org/10.1177/0743558400152003

Guski, R. (1997). Psychological methods for evaluating sound quality and assessing acoustic information. Acta Acustica united with Acustica, 83, 765-774. Retrieved from https://www.researchgate.net/publication/200045182_Psychological_Methods_for_Evaluating_Sound_Quality_and_Assessi ng_Acoustic_Information 
Halpern-Felsher, B. L., Biehl, M., Kropp, R. Y., \& Rubinstein, M. L. (2004). Perceived risks and benefits of smoking: Differences among adolescents with different smoking experiences and intentions. Preventive Medicine, 39, 559-567. https://doi.org/10.1016/j.ypmed.2004.02.017

Hormigos, J. \& Martín Cabello, A. (2004). La construcción de la identidad juvenil a través de la música. Revista Española de Sociología, $\quad 4, \quad 259-270 . \quad$ Retrieved from https://insumisos.com/lecturasinsumisas/Construccion\%20de\%20la\%20identidad\%20juvenil\%20\%20y\%20la\%20musica.pdf

Horn, J. L. (1965). A rationale and test for the number of factors in factor analysis. Psychometrika, 30, 179-185. https://doi.org/10.1007/BF02289447

Inglés, C. J., Méndez, F. X., Hidalgo, M. D., Rosa, A. I., \& Estévez, C. (2003). Evaluación de las habilidades sociales en educación secundaria: revisión de cuestionarios, inventarios y escalas. Psicología Educativa, 9, 71-87. Retrieved from http://journals.copmadrid.org/psed/archivos/88373.pdf

International Organization for Standardization (1990). Acoustics - Determination of occupational noise exposure and estimation of noise-induced hearing impairment. Genève, Switzerland: Author.

Jessor, R. (1991). Risk behaviour in adolescence: A psychosocial framework for understanding and action. Journal of Adolescent Health, 12, 597-605. https://doi.org/10.1016/1054-139X(91)90007-K

Jiang, W., Zhao, F., Guderley, N., \& Manchaiah, V. (2016). Daily music exposure dose and hearing problems using personal listening devices in adolescents and young adults: A systematic review. International Journal of Audiology, 55, 197-205. https://doi.org/10.3109/14992027.2015.1122237

Levey, S., Levey, T., \& Fligor, B. J. (2011). Noise exposure estimates of urban MP3 player users. Journal of Speech, Language, and Hearing Research, 54, 263-277. https://doi.org/10.1044/1092-4388(2010/09-0283)

Lorenzo-Seva, U. \& Ferrando, P. J. (2013). FACTOR 9.2: A comprehensive program for fitting exploratory and semiconfirmatory factor analysis and IRT models. Applied Psychological Measurement, 37, 497-498. https://doi.org/10.1177/0146621613487794

Lorenzo-Seva, U., Timmerman, M. E., \& Kiers, H. A. L. (2011). The Hull method for selecting the number of common factors. Multivariate Behavioral Research, 46, 340-364. https://doi.org/10.1080/00273171.2011.564527

McNeill, K., Keith, S. E., Feder, K., Konkle, A. T. M., \& Michaud, D. S. (2010). MP3 player listening habits of 17 to 23 year old university students. The Journal of the Acoustical Society of America, 128, 646-653. https://doi.org/10.1121/1.3458853

Miller, C. H., Burgoon, M., Grandpre, J. R., \& Alvaro, E. M. (2006). Identifying principal risk factors for the initiation of adolescent smoking behaviors: The significance of psychological reactance. Health Communication, 19, $241-252$. https://doi.org/10.1207/s15327027hc1903_6

Mislevy, R. J. \& Bock, R. D. (1990). BILOG 3: Item analysis and test scoring with binary logistic models. Mooresville, IN: Scientific Software.

Miyara, F. (2005, September/October). Ruido y contenido semántico. Paper presented at the Segundas Jornadas Multidisciplinarias sobre Violencia Acústica Social, Rosario, Argentina.

Morata, T. C. (2007). Young people: Their noise and music exposures and the risk of hearing loss. International Journal of Audiology, 46, 111-112. https://doi.org/10.1080/14992020601103079

Muthén, L. K. \& Muthén, B. O. (2010). Mplus User's Guide (6 ${ }^{\text {th }}$ ed.). Los Angeles, CA: Authors.

Osterlind, S. J. (1990). Establishing criteria for meritorious test items. Educational Research Quarterly, 14(3), 26-30. Retrieved from https://psycnet.apa.org/record/1991-34767-001

National Institutes of Health (2000). Healthy people 2010. Focus area 28: Vision and hearing. Rockville, MD: U.S. Department of Health and Human Services, Office of Disease Prevention and Health Promotion.

Parsons, J. T., Halkitis, P. N., Bimbi, D., \& Borkowski, T. (2000). Perceptions of the benefits and costs associated with condom use and unprotected sex among late adolescent college students. Journal of Adolescence, 23, 377-391. https://doi.org/10.1006/jado.2000.0326

Parsons, J. T., Siegel, A. W., \& Cousins, J. H. (1997). Late adolescent risk-taking: Effects of perceived benefits and perceived risks on behavioral intentions and behavioral change. Journal of Adolescence, 20, 381-392. https://doi.org/10.1006/jado.1997.0094

Quintanilla-Dieck, M. L., Artunduaga, M. A., \& Eavey, R. D. (2009). Intentional exposure to loud music: The Second MTV.com Survey reveals an opportunity to educate. The Journal of Pediatrics, 155, 550-555.e5. https://doi.org/10.1016/j.jpeds.2009.04.053

Rogers, E. M. (2002). Diffusion of preventive innovations. Addictive Behaviors, 27, 989-993. https://doi.org/10.1016/S03064603(02)00300-3

Scientific Committee on Emerging and Newly Identified Health Risks (2008). Potential health risks of exposure to noise from personal music players and mobile phones including a music playing function: Preliminary report. Bruxelles, Belgium: Author.

Serra, M. R., Biassoni, E. C., Hinalaf, M., Abraham, M., Pavlik, M., Pérez Villalobo, J. ... Righetti, A. (2014). Hearing and loud music exposure in 14-15 years old adolescents. Noise \& Health, 16, 320-330. https://doi.org/10.4103/1463-1741.140512

Serra, M. R., Biassoni, E. C., Ortiz Skarp, A. H., Serra, M., \& Joekes, S. (2007). Sound immission during leisure activities and auditory behaviour. Applied Acoustics, 68, 403-420. https://doi.org/10.1016/j.apacoust.2006.03.002

Shrive, F. M., Stuart, H., Quan, H., \& Ghali, W. A. (2006). Dealing with missing data in a multi-question depression scale: A comparison of imputation methods. BMC Medical Research Methodology, 6(1), 1-10. https://doi.org/10.1186/1471-2288-6-57

Siegel, A. W., Cousins, J. H., Rubovits, D. S., Parsons, J. T., Lavery, B., \& Crowley, C. L. (1994). Adolescents' perceptions of the benefits and risks of their own risk taking. Journal of Emotional and Behavioral Disorders, 2, 89-98. https://doi.org/10.1177/106342669400200203

Steinberg, L. (2004). Risk taking in adolescence: What changes, and why? Annals of the New York Academy of Sciences, 1021, 51-58. https://doi.org/10.1196/annals.1308.005

Steinberg, L. (2007). Risk-taking in adolescence: New perspectives from brain and behavioral science. Current Directions in Psychological Science, 16, 55-59. https://doi.org/10.1111/j.1467-8721.2007.00475.x

Steinberg, L. (2008). A social neuroscience perspective on adolescent risk-taking. Developmental Review, $28,78-106$. https://doi.org/10.1016/j.dr.2007.08.002

Sulaiman, A. H., Seluakumaran, K., \& Husain, R. (2013). Hearing risk associated with the usage of personal listening devices among urban high school students in Malaysia. Public Health, 127, 710-715. https://doi.org/10.1016/j.puhe.2013.01.007 
Tabachnick, B. G. \& Fidell, L. S. (2007). Using multivariate statistics (5 ${ }^{\text {th }}$ ed.). Boston, MA: Allyn \& Bacon/Pearson Education.

Twardella, D., Raab, U., Perez-Alvarez, C., Steffens, T., Bolte, G., \& Fromme, H. (2017). Usage of personal music players in adolescents and its association with noise-induced hearing loss: A cross-sectional analysis of Ohrkan cohort study data. International Journal of Audiology, 56, 38-45. https://doi.org/10.1080/14992027.2016.1211762

Valente, T. W. \& Fosados, R. (2006). Diffusion of innovations and network segmentation: The part played by people in promoting health. Sexually Transmitted Diseases, 33(Supplement 7), S23-S31. https://doi.org/10.1097/01.olq.0000221018.32533.6d

Vogel, I., Brug, J., Van der Ploeg, C. P. B., \& Raat, H. (2011). Adolescents risky MP3-player listening and its psychosocial correlates. Health Education Research, 26, 254-264. https://doi.org/10.1093/her/cyq091

Vogel, I., Verschuure, H., van der Ploeg, C. P. B., Brug, J., \& Raat, H. (2009). Adolescents and MP3 players: Too many risks, too few precautions. Pediatrics, 123(Supplement 5), e953-e958. https://doi.org/10.1542/peds.2008-3179

World Health Organization (2015). Hearing loss due to recreational exposure to loud sounds: A review. Retrieved from http://www.who.int/pbd/deafness/Hearing_loss_due_to_recreational_exposure_to_loud_sounds.pdf

Wortman, A. (2001). Aproximaciones conceptuales y empíricas para abordar identidades sociales juveniles y consumos culturales en la sociedad del ajuste (Documentos de Trabajo $\left.\mathrm{N}^{\circ} 24\right)$. Buenos Aires, Argentina: Instituto de Investigaciones Gino Germani/Universidad de Buenos Aires, Facultad de Ciencias Sociales.

Yu, C. -Y. (2002). Evaluating cutoff criteria of model fit indices for latent variable models with binary and continuous outcomes (Doctoral Dissertation, University of California, Los Angeles, CA, United States). Retrieved from http://citeseerx.ist.psu.edu/viewdoc/download;jsessionid=A644E3FAED5E250B235AD1BC31EF2A5E?doi=10.1.1.310.3956 $\&$ rep $=$ rep $1 \&$ type $=$ pdf

Fecha de recepción: Julio de 2016.

Fecha de aceptación: Julio de 2018. 